\title{
Assessment of Undiscovered Oil and Gas Resources of Four East Africa Geologic Provinces
}

Four geologic provinces along the east coast of Africa recently were assessed for undiscovered, technically recoverable oil, natural gas, and natural gas liquids resources as part of the U.S. Geological Survey's (USGS) World Oil and Gas Assessment. Using a geology-based assessment methodology, the USGS estimated mean volumes of 27.6 billion barrels of oil, 441.1 trillion cubic feet of natural gas, and 13.77 billion barrels of natural gas liquids.

\section{Introduction}

The main objective of the U.S. Geological Survey's (USGS) World Petroleum Resources Project is to assess the potential for undiscovered, technically recoverable oil and natural gas resources of the world, exclusive of the United States. As part of this program, the USGS recently completed an assessment of four geologic provinces: three along the eastern part of the African coast and one more than 900 miles east of the African coast and extending to water depths ranging from 2,000-3,000 meters (m) (fig. 1). From north to south, the provinces are as follows: (1) the Tanzania Coastal, containing rift, marginal sag, and passive margin rocks of Middle Jurassic to Holocene age; (2) Seychelles, characterized by rift, marginal sag, and drift rocks; (3) the Morondava, containing failed rift, marginal sag, and passive margin rocks; and (4) the Mozambique Coastal, described by rift, marginal sag, and passive margin rocks. These assessments were based on data from oil and gas exploration wells and published geologic reports.

The four provinces were related to the breakup of Gondwana (fig. 2) in the late Paleozoic and Mesozoic (Reeves and others, 2002), and developed similarly through two tectonic phases (fig. 3): (1) a syn-rift phase that was started during the Permo-Triassic and continued

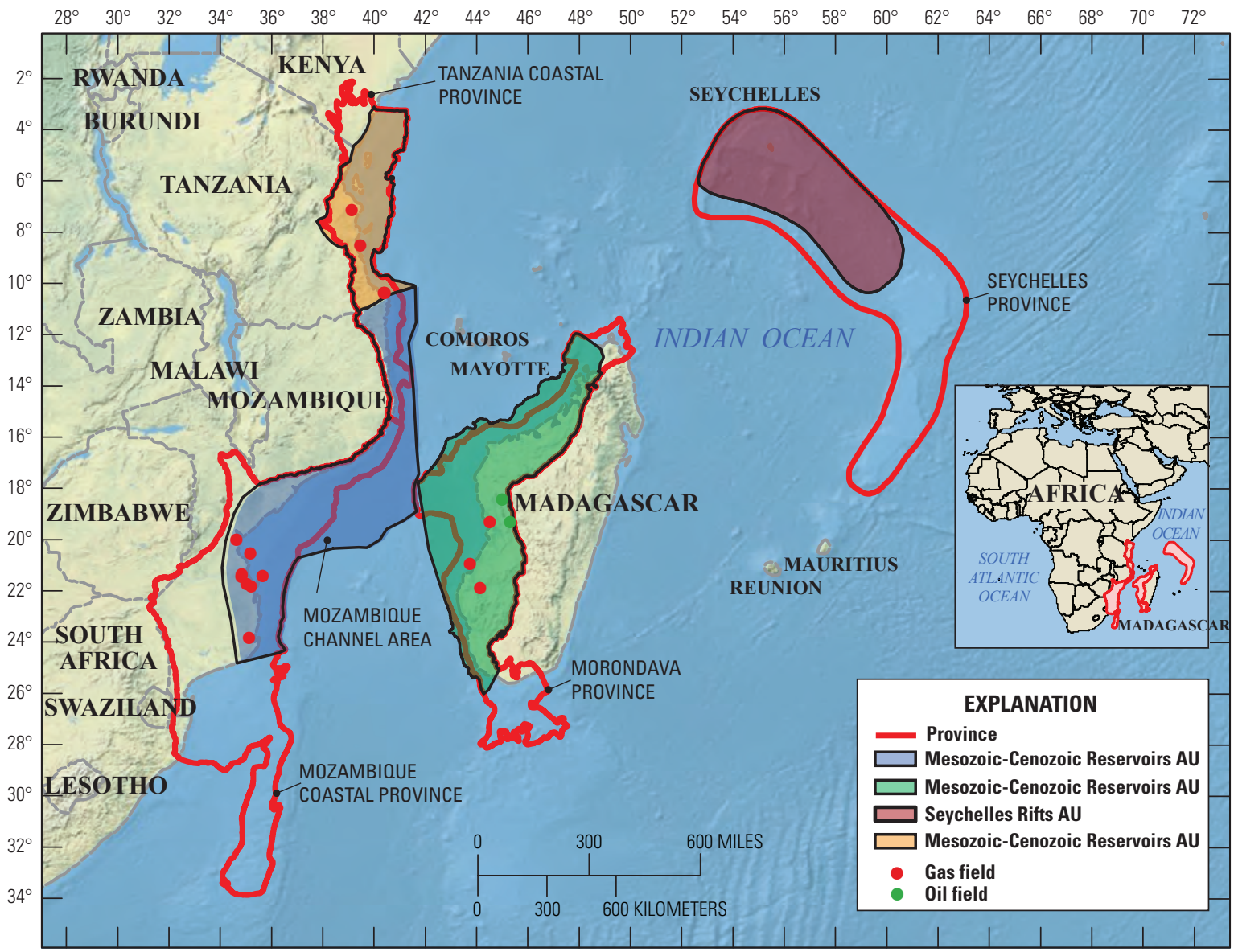

Figure 1. Locations of the four assessed geologic provinces and assessment units (AU) along the central coast of east Africa. 
into the Jurassic, resulting in the formation of grabens and half-grabens and (2) a drift phase that began in the mid-Jurassic and continued into the Paleogene. A later passive margin phase began in the late Paleogene and continues to the present in the Morondava, Mozambique, and Tanzania Coastal Provinces, whereas in the Seychelles Province the drift phase continues to the present because there is no significant sediment source after the Seychelles-India breakup. The total thickness of the Mesozoic to Cenozoic stratigraphic section is more than 5,000 $\mathrm{m}$ on the outer parts of the continental shelf along the east Africa coast in the Morondava and Mozambique Coastal Provinces and more than 4,000 $\mathrm{m}$ in the Seychelles Province.

The four provinces and associated assessment units (AU) were assessed for the first time because of increased exploratory activity, recent discoveries, and increased interest in their future potential. The assessment was geology based and used the total petroleum system (TPS) concept. The geologic elements of a TPS include hydrocarbon source rocks (source rock maturation and hydrocarbon generation and migration), reservoir rocks (quality and distribution), and traps for hydrocarbon accumulation.

Using these geologic criteria, the USGS defined four TPSs and one AU for each TPS (table 1). The TPSs were defined to include Mesozoic to Paleocene source rocks and conventional reservoirs (fig. 3). The Permian to Triassic contains fluvial and lacustrine source rocks, and the Jurassic contains restricted marine Type II kerogen source rocks and marginal marine and deltaic Types II and III kerogen source rocks. Types II and III kerogen source rocks of Cretaceous age have been identified in the Morondava, Mozambique, Seychelles, and Tanzania Provinces, and Types II and III kerogen source rocks of Paleogene age have been identified in Mozambique, Seychelles, and Tanzania Provinces. Permian to Triassic source rocks contain 1.0 to 6.7 weight percent total organic carbon (TOC), with some samples having as much as 17.4 percent. The Early to Middle Jurassic restricted marine Type II source rocks contain as much as 12 weight percent TOC. Upper Jurassic and Cretaceous marine strata include (1) Aptian source containing Type II kerogen, ranging from 2.0 to 4.28 weight percent TOC; and (2) Cenomanian-Turonian source rocks containing Type II kerogen, ranging from 1.0 to 3.0 weight percent TOC. All four AUs contain Mesozoic and Cenozoic clastic reservoirs. Traps are mostly structural within the syn-rift rock units and both structural and stratigraphic in the postrift-rock units. The east African provinces (Mozambique, Morondava, and Tanzania, fig. 1) contain reservoirs that mostly are associated with growth-fault-related structures, rotated fault blocks within the continental shelf, deep water fans, turbidite channels and sandstones, slope truncations along the present-day shelf and paleoshelf edge. Permian to Triassic sandstone and Late Jurassic reefs and platform limestone also are possible reservoirs. The primary seals are Mesozoic and Cenozoic mudstones and shales. The Seychelles Province contains possible reservoirs in Permian to Middle Jurassic rift-related sandstones, Middle Jurassic carbonates, Lower and Upper Cretaceous turbidite sandstones, and Tertiary carbonates. The primary seals are intraformational shales.

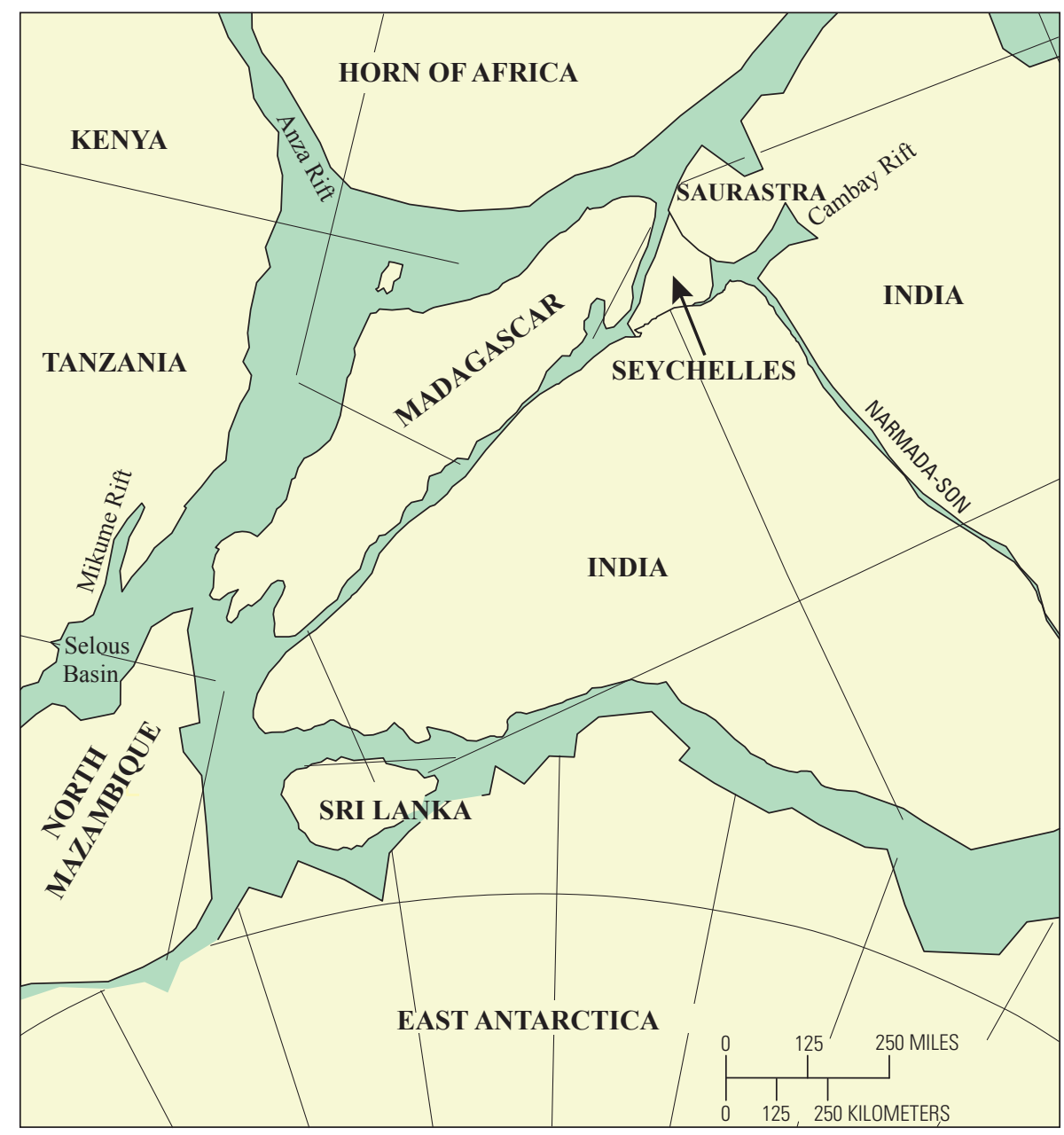

Figure 2. Reconstruction of the early breakup of Gondwana during the Early Jurassic (200 Ma) showing the Precambrian crustal fragments in yellow and the rift-related rocks in light green. Modified after Reeves and others (2002). 
Table 1. Morondava, Mozambique Coastal, Seychelles, and Tanzania Coastal Provinces assessment results for undiscovered, technically recoverable oil, gas, and natural gas liquids.

[Largest expected mean field size, in million barrels of oil and billion cubic feet of gas; MMBO, million barrels of oil; BCFG, billion cubic feet of gas; MMBNGL, million barrels of natural gas liquids. Results shown are fully risked estimates. For gas accumulations, all liquids are included as natural gas liquids (NGL). Undiscovered gas resources are the sum of nonassociated and associated gas. F95 represents a 95-percent chance of at least he amount tabulated; other fractiles are defined similarly. $\mathrm{AU}$, assessment unit; AU probability is the chance of at least one accumulation of minimum size within the AU. TPS, total petroleum system. Gray shading indicates not applicable]

\begin{tabular}{|c|c|c|c|c|c|c|c|c|c|c|c|c|c|c|}
\hline \multirow{3}{*}{$\begin{array}{c}\text { Total petroleum systems } \\
\text { (TPS) and assessment } \\
\text { units (AU) }\end{array}$} & \multirow{3}{*}{$\begin{array}{l}\text { Field } \\
\text { type }\end{array}$} & \multirow{3}{*}{\begin{tabular}{|l|} 
Largest \\
expected \\
mean \\
field size
\end{tabular}} & \multicolumn{12}{|c|}{ Total undiscovered resources } \\
\hline & & & \multicolumn{4}{|c|}{ Oil (MMBO) } & \multicolumn{4}{|c|}{ Gas (BCFG) } & \multicolumn{4}{|c|}{ NGL (MMBNGL) } \\
\hline & & & F95 & F50 & F5 & Mean & F95 & F50 & F5 & Mean & F95 & F50 & F5 & Mean \\
\hline \multicolumn{15}{|c|}{ Morondava-Mesozoic Composite TPS } \\
\hline \multirow{2}{*}{$\begin{array}{l}\text { Mesozoic-Cenozoic } \\
\text { Reservoirs AU }\end{array}$} & Oil & 1,016 & 5,701 & 10,256 & 17,455 & 10,750 & 7,686 & 14,325 & 25,323 & 15,123 & 205 & 386 & 693 & 409 \\
\hline & Gas & 7,837 & & & & & 85,291 & 145,683 & 242,887 & 152,096 & 2,667 & 4,569 & 7,618 & 4,767 \\
\hline $\begin{array}{l}\text { Total conventional } \\
\text { resources }\end{array}$ & & & 5,701 & 10,256 & 17,455 & 10,750 & 92,977 & 160,008 & 268,210 & 167,219 & 2,872 & 4,955 & 8,311 & 5,176 \\
\hline \multicolumn{15}{|c|}{ Mozambique Coastal-Mesozoic Composite TPS } \\
\hline \multirow{2}{*}{$\begin{array}{l}\text { Mesozoic-Cenozoic } \\
\text { Reservoirs AU }\end{array}$} & Oil & 1,041 & 6,268 & 11,174 & 18,857 & 11,682 & 8,423 & 15,615 & 27,238 & 16,425 & 225 & 421 & 744 & 444 \\
\hline & Gas & 7,976 & & & & & 93,486 & 158,654 & 263,301 & 165,924 & 2,915 & 4,978 & 8,270 & 5,201 \\
\hline $\begin{array}{l}\text { Total conventional } \\
\text { resources }\end{array}$ & & & 6,268 & 11,174 & 18,857 & 11,682 & 101,909 & 174,269 & 290,539 & 182,349 & 3,140 & 5,399 & 9,014 & 5,645 \\
\hline \multicolumn{15}{|c|}{ Seychelles-Mesozoic-Cenozoic Composite TPS } \\
\hline \multirow{2}{*}{ Seychelles Rifts AU } & Oil & 793 & 585 & 1,984 & 5,574 & 2,394 & 1,328 & 4,760 & 15,038 & 6,044 & 28 & 100 & 324 & 129 \\
\hline & Gas & 4,765 & & & & & 3,538 & 11,781 & 33,660 & 14,332 & 146 & 496 & 1,467 & 610 \\
\hline $\begin{array}{l}\text { Total conventional } \\
\text { resources }\end{array}$ & & & 585 & 1,984 & 5,574 & 2,394 & 4,866 & 16,541 & 48,698 & 20,376 & 174 & 596 & 1,791 & 739 \\
\hline \multicolumn{15}{|c|}{ Tanzania Coastal-Mesozoic-Cenozoic Composite TPS } \\
\hline \multirow{2}{*}{$\begin{array}{l}\text { Mesozoic-Cenozoic } \\
\text { Reservoirs AU }\end{array}$} & Oil & 594 & 1,223 & 2,608 & 5,064 & 2,806 & 1,583 & 3,555 & 7,571 & 3,933 & 42 & 95 & 208 & 106 \\
\hline & Gas & 6,162 & & & & & 35,902 & 64,054 & 108,925 & 67,174 & 1,118 & 2,006 & 3,433 & 2,106 \\
\hline $\begin{array}{l}\text { Total conventional } \\
\text { resources }\end{array}$ & & & 1,223 & 2,608 & 5,064 & 2,806 & 37,485 & 67,609 & 116,496 & 71,107 & 1,160 & 2,101 & 3,641 & 2,212 \\
\hline $\begin{array}{l}\text { Total conventional } \\
\text { resources }\end{array}$ & & & 13,777 & 26,022 & 46,950 & 27,632 & 237,237 & 418,427 & 723,943 & 441,051 & 7,346 & 13,051 & 22,757 & 13,772 \\
\hline
\end{tabular}

At the time of the assessment, the four east African provinces contained 1 oil and 11 gas accumulations (HIS Energy, 2009), thus exceeding the minimum size of 5 million barrels of oil equivalent and 30 billion cubic feet of gas; these provinces are considered to be underexplored for their size. The Seychelles Province contained no discoveries and was also underexplored.

Exploration wells and discovered accumulations on the continental shelf and upper slope (IHS Energy, 2009) provide evidence for (1) the existence of an active petroleum system containing Mesozoic source rocks, (2) the migration of the hydrocarbons most likely since the Late Cretaceous, and (3) the migration of the hydrocarbons into Cretaceous and Cenozoic reservoirs.

\section{Resource Summary}

The results of the USGS assessment of undiscovered, technically recoverable conventional oil and gas resources in the east Africa provinces are listed in table 1 . The mean volumes are estimated at (1) 10,750 million barrels of oil (MMBO), 167,219 billion cubic feet of gas (BCFG), and 5,176 million barrels of natural gas liquids (MMBNGL) for the Mesozoic-Cenozoic Reservoirs AU in the Morondava Province; (2) 11,682 MMBO, 182,349 BCFG, and 5,645
MMBNGL for the Mesozoic-Cenozoic Reservoirs AU in the Mozambique Coastal Province; (3) 2,394 MMBO, 20,376 BCFG, and 739 MMBNGL for the Seychelles Rifts AU in the Seychelles Province; and (4) 2,806 MMBO, 71,107 BCFG, and 2,212 MMBNGL for the Mesozoic-Cenozoic Reservoirs AU in the Tanzania Coastal Province. For this assessment, a minimum undiscovered field size of 5 million barrels of oil equivalent (MMBOE) was used. No attempt was made to estimate economically recoverable reserves.

\section{For Additional Information}

Assessment results are available at the USGS Central Energy Resources Science Center website: http://energy.cr.usgs.gov/ oilgas/noga/ or contact Michael E. Brownfield, the assessing geologist (mbrownfield@usgs.gov).

\section{East Africa Provinces Assessment Team}

Michael E. Brownfield, Christopher J. Schenk, Ronald R. Charpentier, Timothy R. Klett, Troy A. Cook, Richard M. Pollastro, and Marilyn E. Tennyson. 


\section{References Cited}

Fugro Multi Client Services, 2010, New Seychelles, non-exclusive 2D seismic survey: Accessed March 6, 2012, at http://www.fugromcs. com.au/Fliers/Flier_Seychelles.pdf.

IHS Energy, 2009, International petroleum exploration and production database [current through December 2009]: Available from IHS

Energy, 15 Inverness Way East, Englewood, CO 80112 USA.
Reeves, C.V., Sahu, B.K., and de Wit, M., 2002, A re-examination of the paleo-position of Africa's eastern neighbours in Gondwana: Journal of African Earth Sciences, v. 34, no. 1, p. 101-108.

Rusk, Bertagne \& Associates, 2003, Petroleum geology and geophysics of the Mozambique Channel, executive summary: Accessed March 6, 2012, at http://www.petrocommunicators.com/moz/index.htm.
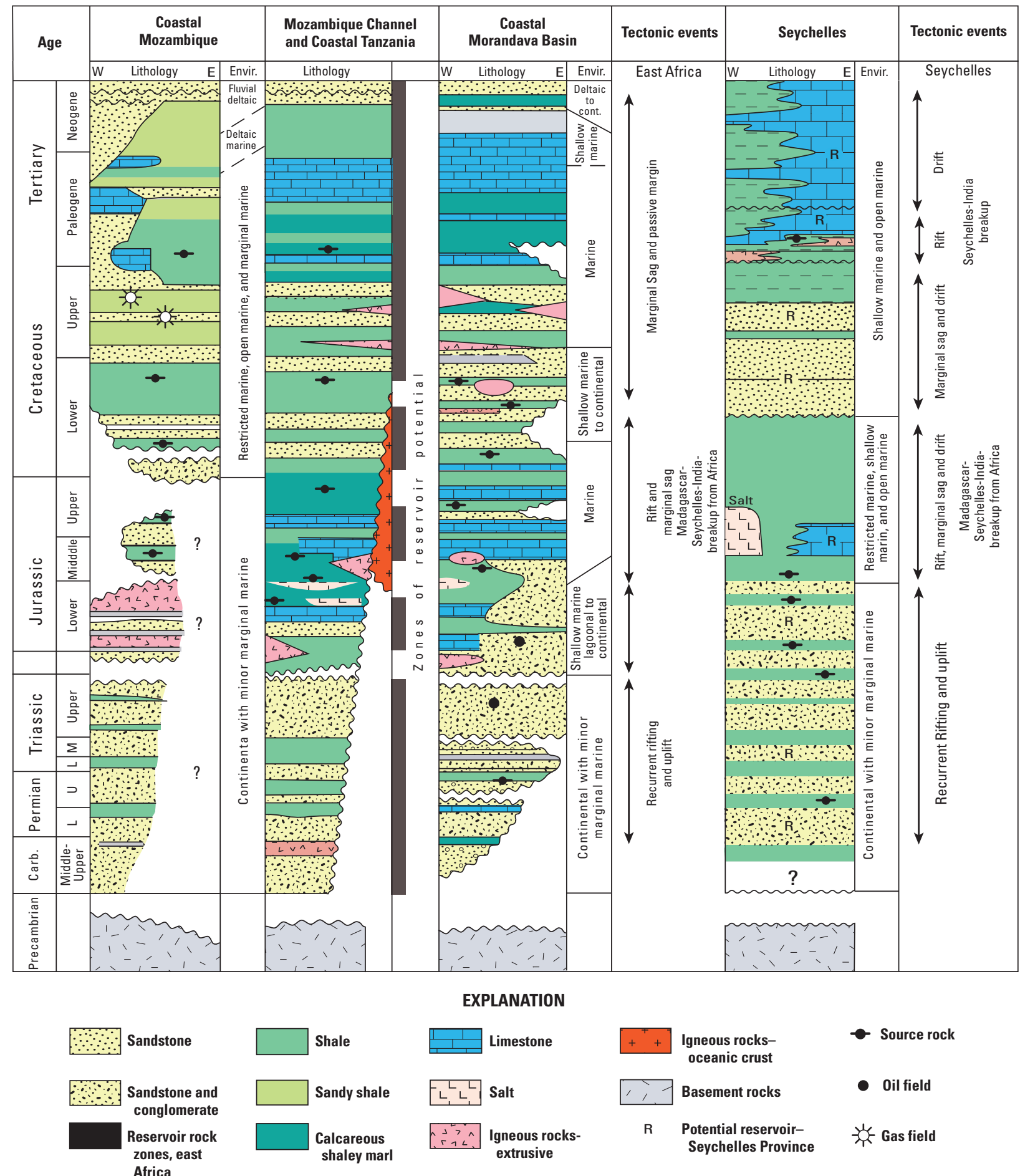

Figure 3. Generalized stratigraphic columns for Mozambique Coastal, the Mozambique Channel and Tanzania Coastal, and the Morondava and Seychelles Provinces along the east coast of Africa (see fig. 1). Carb., Carboniferous; cont., continental; Envir., environment; L, Lower; M, Middle; U, Upper; ?, questionable extent. Modified after Fugro Multi Client Services (2010) and Rusk, Bertagne \& Associates (2003). 